Original scientific paper

UDK: 327(316.774):329(323(4))

DOI: $10.5937 /$ jrs15-24300

Received: 4 December 2019 / Accepted: 28 April 2020

\title{
Populism and Foreign Policy: An Assessment and a Research Agenda
}

\author{
WOUTER LAMMERS* \\ Utrecht University, the Netherlands \\ MICHAL ONDERCO** \\ Erasmus University Rotterdam, the Netherlands
}

\begin{abstract}
Populist parties are often seen as a threat to liberal democracy domestically, and in the international arena, they are often accused of unwillingness to support a liberal international order. We study how what we know about foreign policy preferences of populist parties is driven by how we study the phenomenon; and how we can fix the shortcomings which exist in the literature. To sketch a future research agenda, we first conduct a systematic review of the literature on the foreign policy views of populist parties in Europe and investigate how what we know is driven by how we know it. We look at the themes of foreign policy, research methods, as well as the parties and countries in researchers' focus. Our findings indicate that skewed focus on particular countries and parties combined with a uniform use of methods contributes to a lack of detailed understanding of populist views on foreign policies. We propose future avenues of research into the foreign policy views of populist parties, including a diversification of methods and more in-depth empirical and cross-national studies on specific themes.
\end{abstract}

Keywords: populism; foreign policy, literature review, Europe, political parties

\footnotetext{
*lammerswouter@gmail.com

*onderco@essb.eur.nl
} 


\section{Introduction}

Populism has increasingly gained momentum in Europe since the end of the Cold War in $1989^{1}$ and populist parties have firmly established an electorate in various countries. Populist views have shifted from the margin to the mainstream in Europe since the early 1990 s. $^{2}$ Populist parties have succeeded in becoming coalition partners in Italy, ${ }^{3}$ the Netherlands $^{4}$ and Austria ${ }^{5}$ as well as the ruling parties in Hungary ${ }^{6}$ and Greece. Their electorate consists mainly of protest voters opposed to the supposed "corrupt elite". Commentators consider populism to pose a threat to liberal democracy in Europe. ${ }^{8}$ Populists are also seen as those who are unwilling to support the liberal international order, and focus on narrowly defined national self-interest.

Among scholars, the study of populism and foreign policy combines two appealing aspects. On the one hand, it is the inherent attraction stemming from the interest in the study of populists as a subject of much scholarly and popular attention. At the same time, the scholarly study of political parties and foreign policy has experienced a sharp increase in attention. ${ }^{9}$ Accepting that parties matter for states' foreign policy, and given the relevance of populist parties in contemporary politics, the study of populist parties' foreign policy preferences is both essential and popular.

In this paper, we contribute to the research on foreign policies in light of the populist zeitgeist,$^{10}$ by reviewing existing research, and sketching a future research agenda. In particular, we aim at answering three questions: how do we know what we know about the foreign policy of populist parties in Europe; how have these "ways of knowing" contributed to "what we know" about it; and how can future research address the existing shortcomings. We base our findings on a comprehensive overview of the foreign policy views of populist parties, in line with the PRISMA principles of systematic reviewing. ${ }^{11}$ It is important to note up front that our paper is interested in the study of foreign policy and populism in Europe. While there is a long and distinguished tradition of studying

1 Betz 1994; Rooduijn 2014.

2 Betz, 1994.

3 Albertazzi and McDonnell 2005; Horowitz 2018.

$4 \quad$ Van Kessel 2011.

5 Heinisch 2003; Slawson 2017.

6 Enyedi 2016.

7 Schumacher and Rooduijn 2013.

8 Hirsch Ballin 2011; Jenne and Mudde 2012; Szirtes 2018; Taguieff 1995.

9 Joly and Dandoy; 2016; Mello 2014; Raunio and Wagner 2017; Wagner, Herranz-Surralles, Kaarbo, and Ostermann 2017.

10 Mudde 2004.

11 Liberati et al. 2009. 
populism and foreign policy outside Europe ${ }^{12}$ we do not include it here, because of space constraints.

The remainder of the paper continues as follows: in the second section, we briefly outline why paying attention to populist parties makes sense and what do we understand by populism. The third section will outline the methodology of the study. The fourth and fifth sections present the results of the study, looking at both methodology of the existing studies, and the consequences thereof. In the concluding section, we summarize the findings and sketch possible future avenues of research.

\section{Theoretical Background}

\section{Why Looking at Parties and their Foreign Policy}

The study of parties in foreign policy falls within the innenpolitik stream of foreign policy analysis. ${ }^{13}$ As argued by Moravcsik, ${ }^{14}$ interests and ideology of groups in society, and the way coalitions are built between these groups in order to achieve their goals for foreign policies, shape the foreign policy of a state. This approach recognizes that countries are not internally unified about foreign policies and that the domestic political debate does influence the actual foreign policy of a country.

Political parties are especially important in this aspect. They emerged as a result of social conflict ${ }^{15}$ and represent their electorate in the parliament and continuously seek ways to "secure access to the tools of policy making." ${ }^{16}$ Political parties abide by two goals: controlling seats in the legislature and wielding power in the ruling coalition or cabinet. ${ }^{17}$ They often succeed in their mission of influencing their nation's foreign policy. ${ }^{18}$

According to the dominant cleavage theory, parties form preferences based upon their long-standing ideological agendas that reflect existing divisions in society. ${ }^{19}$ Party ideology forms their weltanschauung or the prism through which they look at policy debates. When conflict arises over new issues, it will be perceived from the perspective of the

12 For some fine examples, see Dodson and Dorraj 2008; Halliday 2016; Plageman and Destradi 2019; Sagarzazu and Thies 2019.

13 Fearon 1998; Hudson 2005.

14 Moravcsik 1997.

15 Lipset and Rokkan 1967.

16 Koch 2009, 801.

17 Browne and Franklin 1973; Lupia and Strom 1995.

18 Palmer et al. 2004; Schuster and Maier 2006.

19 Lipset and Rokkan 1967; Zuckerman 1982. 
party's ideology and embedded in their agenda. ${ }^{20}$ Thus, existing cleavages remain longstanding because they accommodate new conflicts. ${ }^{21}$ Existing research has focused on the left/right axis of conflict, which animated much of the scholarship in other areas of public policy and political science. ${ }^{22}$

Left-wing political parties, in contrast to right-winged ones, strive for an egalitarian society and sympathize with a strong role of the state in the economy. ${ }^{23}$ When it comes to international conflict, right-wing parties have been found to resemble hawks, in contrast to the left-wing doves. ${ }^{24}$ However, the recent work of Wagner et al ${ }^{25}$ suggests that the relationship between support for military missions is curvilinear: radical left and right parties are less supportive than center-right and center-left ones. Left-wing parties favor spending on the welfare state over military expenses. ${ }^{26}$ The left-right division also reflects differences concerning international economic policies, such as international aid $^{27}$ and trade. ${ }^{28}$

\section{What is Populism?}

Common use of the word populism refers to a fierce style of communication and simplistic policy proposals based on gut-feeling and extreme opinions, often on the right wing of the political spectrum. Although populist politicians have often been reported to adopt a more "rough" style of communication, populism is more than just a style. ${ }^{29}$

As Rovira Kaltwasser et al..$^{30}$ argue, scholars have adopted four basic definitions of populism: ideational, socioeconomic, strategic, and stylistic. According to Aslanidis ${ }^{31}$, the most widespread definition in academia of populism is the "ideational" definition by Cas Mudde. This definition goes beyond populism as mere demagogy or lack of realism, and instead focuses on the basic underlying characteristics of populist ideology: the battle between the pure people versus the corrupt elite. Mudde $^{32}$ defines populism as "an ideology that considers society to be ultimately separated into two homogeneous and antagonistic

20 Marks, Wilson, and Ray 2002.

21 Kriesi et al. 2006; Wagner et al. 2017.

22 Wagner et al. 2018.

23 Wagner et al. 2017.

24 Russett 1990; Budge and Hofferbert 1990; Klingemann et al. 1994; Palmer, London, and Regan 2004; Schuster and Maier 2006; Koch and Cranmer 2007.

25 Wagner et al. 2017.

26 Van der Brug 2001; Koch and Sullivan 2010.

27 Jerneck et al. 1988; Hiscox 2002; Milner and Tingley 2015; Thérien and Noel 2000.

28 Milner and Judkins 2004.

29 Mudde 2004.

30 Rovira Kaltwasser et al. 2017.

31 Aslanidis 2016.

32 Mudde 2004. 
groups, 'the pure people' versus 'the corrupt elite', and which argues that politics should be an expression of the volonté générale (general will) of the people."33 The Rousseauian concept of the volonté generale lies at the core of this conceptualization: we, the people, form a unity with one real opinion, often named common sense. ${ }^{34}$ Anyone standing between the pure people and the fulfillment of their wishes must be moved aside for violating the sovereignty of the people. ${ }^{35}$ Because the elite has become corrupt, too weak or deaf to the wishes of the people, they are no longer fit to rule the country. Instead, the populist politician moves himself forward as the legitimate one to rule.

The concept of "the pure people" is often kept ambiguous, even by populist politicians themselves, but based on their discourse some notions of the concept have been distilled. "The pure people", in the discourse of populist leaders, often do not include the complete population of a country, but instead an example of what the people 'really are', in short "virtuous and unified". ${ }^{6}$ "The pure people" have not been infected by any nonsensical political views, but must watch their country sliding back for centuries because the corrupt elite does not listen to them anymore. Examples of the labels used to depict the pure people would be Middle England, Joe the Plumber in the US, or Henk and Ingrid in the Netherlands. ${ }^{37}$

The political view of anti-elitism and people-centrism forms a so-called "thin ideology" 38 This means that it does not consist of an in-depth ideology, but rather a "restricted core, attached to a narrower range of political concepts", ${ }^{39}$ one that can be attached to any political scheme. Thus, populism has known bedfellows on all sides of the political spectrum, such as nationalist, socialist and regionalist. ${ }^{40}$ This central characteristic of populism makes it especially hard, and at the same time relevant, to predict a populist party's foreign policy view.

33 Mudde 2014, 543.

34 Greven 2016.

35 Mudde and Rovira Kaltwasser 2013.

36 Taggart 2000.

37 Mudde 2004.

38 Stanley 2008.

39 Freeden 1998, 750.

40 Stanley 2008; Verbeek and Zaslove 2015. 


\section{Methods}

We start by conducting a literature review to identify all relevant scientific studies published since 1989 on the topic of populism and foreign policy. Given that the study of populism originated in Europe, and given that the majority of studies focus on Europe, we also decided to focus on Europe in this paper. This does not mean that scholarship focusing on cases outside Europe is less sophisticated or developed - indeed, the study of both Western $^{41}$ and non-Western countries ${ }^{42}$ outside Europe yielded important insights. Our decision is mainly pragmatic, driven by restrictions on the length of this paper.

\section{Literature Search}

To start off, we compiled a list of search terms in English, French, and German. ${ }^{43}$ These can be found in Table 1. A shortlist of search terms was designed, consisting of four terms on populism which were based on the literature on populism and two terms that were derived from the field of international relations. Every search was conducted using a combination of the terms from both of the fields, leading to $4 \times 2=8$ search term combinations. In order to exclude studies on populism and foreign policy in other continents, the term "Europe" was added for every search. For an overview of search terms, see Table 1.

\begin{tabular}{|l|l|l|}
\hline English & French & German \\
\hline populis(t/m) & populis(te/me) & populis(t/mus) \\
\hline far-right & extrême droite & ganz rechts \\
\hline far-left & extrême gauche & ganz links \\
\hline political part(y/ies) & parti(s) politique(s) & politische partei(en) \\
\hline
\end{tabular}

in combination with:

\begin{tabular}{|l|l|l|}
\hline foreign polic(y/ies) & politique extérieure & Außenpolitik \\
\hline europ(e/ean) & europ(e/éen) & europ(a/äisch) \\
\hline
\end{tabular}

Table 1: Search Terms

41 Boucher and Thies 2019; Friedrichs 2019.

42 Dodson and Dorraj 2008; Halliday 2016; Plageman and Destradi 2019.

43 We selected these languages pragmatically - based on the skills of the authors, but also because they represent the dominant languages for academic publishing in Europe. 
Once this list was completed, we performed a systematic search for articles via three search databases: Web of Science, CEEOL and CAIRN.info. We selected these databases because they represented major sources for academic writings in English, French, and those coming from Eastern Europe. In the latter region, the study of populism has been ongoing for some time, but often without communication with scholarship elsewhere, making inclusion into this analysis especially relevant. ${ }^{44}$ While we did not search for studies in Central and Eastern European languages, we managed to include a number of studies by scholars from this region. Given that there is no comparable database for Germanspeaking journals, we also searched the tables of contents of IP Internationale Politik; Zeitschrift für Vergleichende Politikwissenschaft; Zeitschrift für Aussen- und Sicherheitspolitik; Politische Vierteljahrschrift.

Then, we used snowballing, to identify papers which we missed earlier. Articles that were cited by relevant studies were checked for eligibility and included in the selection if they met the selection criteria. At this stage, we also found, and decided to include studies in Dutch (another language the authors speak).

All in all, we identified a total of 6659 articles. We then examined their abstracts and titles. Some papers were excluded immediately, because they did not actually deal with populism and/or foreign policy. Figure 1 depicts the process of arriving at an evaluated selection of articles in line with the PRISMA flowchart. ${ }^{45}$ The PRISMA principles intend to stimulate transparency and completeness of reporting on systematic reviews with a 27item checklist. Examples of these items are explicit reporting on the rationale, objectives, eligibility criteria and search strategy. We do not fully comply with all the steps as specified by the original PRISMA flowchart: for example, the number of overlapping studies in the longlists acquired with the first search could not be established. However, we do adhere to the basic PRISMA principles of reporting on systematic reviews. The full list of included articles can be found in Appendix 1.

44 On the relationship between Central European IR and the rest of the discipline, see the forum in Journal of International Relations and Development, edited by Drulák 2009.

45 Liberati et al. 2009. 


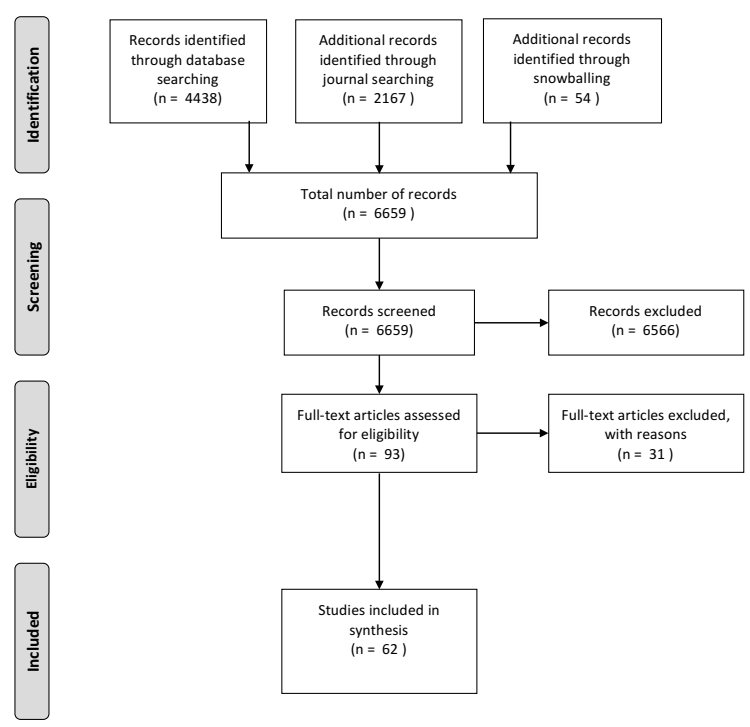

Figure 1: PRISMA Flow Diagram

The vast majority of studies identified through snowballing was related to Euroscepticism, a finding expectable given the increasingly receiving scholarly attention given to it. ${ }^{46}$ We focused, however, on finding articles on all themes of foreign policy. To keep an article in the selection, we followed four simple rules. Firstly, the article must discuss the foreign policy preferences held by a political party that it considers as populist or representing populism. Articles on parties with a reference to "radical" or "extreme" in the title or abstract were evaluated, but if the political party in the article was not considered populist by the article's author, the study was excluded.$^{47}$ Secondly, the article should be published in the period from 1989 up to and including 2017 and discuss foreign policy preferences in this period of time. Thirdly, to be included, a study had to consider political parties that operate at a national or EU level. Regionalist parties, such as Lega Nord or Vlaams Blok do fit this selection criterion because they represent their electorate in the national parliament. Fourthly, studies were included if published in English, French, German or Dutch.

\section{Review Method and Coding}

The final selection of articles was read and analyzed using a coding scheme specifically designed for this study. Coding categories were included on the characteristics of the

46 Pirro and Taggart 2018.

47 This is also why we excluded studies that investigated solely the extreme right, e.g. those masterfully reviewed by Umland 2017. 
article and of the party, or parties, studied. The following categories were included in the coding scheme: research method, research scope, political party characteristics and theme. The full coding scheme including definitions can be found in Appendix 2. No coding categories are mutually exclusive. When it comes to the methods of the study, two sections are especially relevant. Ideally, studies empirically substantiate their claims on (1) why a certain political party should be labeled as populist, and (2) what foreign policy preferences this populist party holds.

The coding of the 'theme' is based on the codebook of the Comparative Manifesto Project. ${ }^{48}$ To these categories, "migration" was added, as this has often been argued to be a matter of international negotiations. ${ }^{49}$ Migration involves, by definition, the crossing of borders and thus touches directly upon the relations between these countries.

Coding categories were assigned to a publication only in the cases of explicit reference to this category. For example, in case of the category "research method", if it was not clear what the sources were for arguments about preferences of a populist party on a certain subject of international relations, this was coded as no method. We did not discriminate between quantitative and qualitative designs. For example, a social media analysis could be carried out in a quantitative or a qualitative manner, and in both cases be coded as "social media analysis".

In total, we ended up with 62 studies. More than one third of these was published in 2015 and 2016 (11 in 2015 and 13 in 2016). Surprisingly, we found no study meeting our criteria that was published between 1989 and 1998. Although it is widely agreed upon that populism existed before 1998, it might be that prior to 1998 scholars would not focus on populists' foreign policy views as only one of them - Lega Nord - was in power at that time. From the selected studies, 52 studies were in English, 7 studies in German, 2 studies in French and 1 in Dutch.

\section{How Do We Know What We Know About Populist Foreign Policy?}

Let us start by looking at how we know what we know about research on populist parties.

\section{Research Methods}

We coded the use of methods for all studies. Figure 4 displays the distribution of reported methods among the studies. We should reiterate that methods were not coded mutually exclusive: in fact, a substantial number of studies report the use of more than one method. On the other hand, nine papers did not state any method of analysis (and no systematic method could be ascertained from reading the papers). In addition, six papers were purely

48 Werner et al. 2015.

49 Lavenex 2006; Mitchell 1989. 
theoretical. Among these was an exceptionally influential publication by Taggart, ${ }^{50}$ which was, at the time of writing this, cited more than 340 times on Web of Science. This study serves as one of the cornerstones of the theoretical framework on populism in the current body of literature.

The vast majority of the studies based their findings on manifesto analysis (48) or traditional media analysis (36). A lesser number of studies focused on the analysis of parliamentary behavior (14) or literature review (5). Despite being common among International Relations scholars, very few studies used interviews of political actors (3). Only one study investigated political statements on social media. ${ }^{51}$ Although some studies ${ }^{52}$ made use of expert survey data gathered by the Chapel Hill Expert Survey research project, ${ }^{53}$ none of the studies included their own expert survey. ${ }^{54}$ Six studies could be identified best as theoretical or conceptual papers with explorative theorizing.

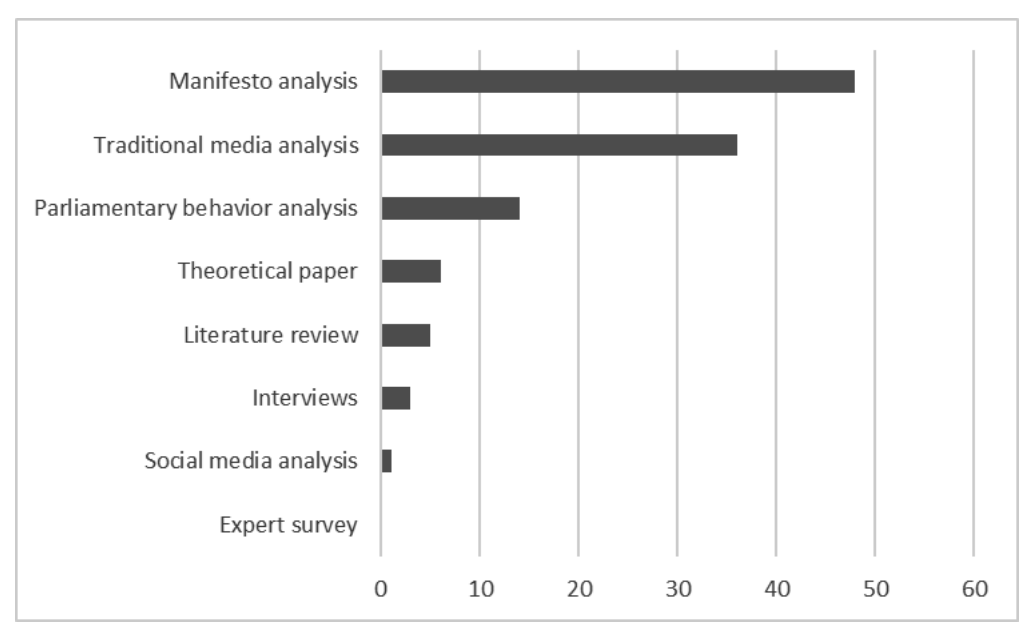

Figure 2: Which methods are used?

It is no surprise that manifesto analysis was the most popular method. We defined manifesto analysis relatively broadly, by incorporating all texts written by the political party or its leadership. This would include online publications and even books, too. Although the largest share of party texts were official election manifestos, these other types were frequently analyzed as well. For example, the study by Chryssogelos combines online party

50 Taggart 1998.

51 Cincu 2017.

52 Jungar and Jupskås 2014; Van Spanje and Van der Brug 2007.

53 Bakker et al. 2010; Marks et al. 2017.

54 Because it was not published in an academic journal, we did not include the study of Gressel $2017 \mathrm{a}$, although that one would be an expert survey. 
publications with official electoral manifestos, ${ }^{55}$ and the study by Mudde ${ }^{56}$ made use of the number of books that the leader of a given populist party had written. Not surprisingly, the study of actual electoral manifestos has often not been conducted in a systematic way, but rather focused on cherry-picking certain segments. Two studies made use of the Parliamentary Manifesto Database. ${ }^{57}$ The same applies to traditional media analysis: it is used frequently, but without a broader systematic basis. As an illustration, Hartleb cites a handful of party expressions in the media, but does not develop a broader empirical support. $^{58}$

Studies that investigate parliamentary behavior generally do so in a qualitative manner. For example, Novaković looked at the coalition between a center-right and extreme-right political party, ${ }^{59}$ and the study by Petsinis draws upon a discourse analysis on Greek-Russian relations and national populism that includes parliamentary speeches. ${ }^{60}$ However, by and large, such studies has been devoid of systematic quantitative study. ${ }^{61}$

Research using interviews used a small number of interviewees, as is usual in the research tradition relying on elite interviewing..$^{62}$ Even by these standards, however, existing scholarship on populism and foreign policy has been relying on very small numbers of cases. While the study by Fitzgibbon \& Guerra ${ }^{63}$ reports one interview and Albertazzi \& McDonnell ${ }^{64}$ held three interviews, the study by Jungar \& Jupskås held probably five interviews (the exact number was not reported). ${ }^{65}$

Only one study in our sample conducted social media analysis ${ }^{66}$ which was also triangulated by extensive use of other empirical observations, including multiple media expressions, speeches, and various other party texts.

55 Chryssogelos 2010.

56 Mudde 2016.

57 Dobos and Gyulai 2015 and Jungar and Jupskås 2014; for Parliamentary Manifesto Database, see Budge et al. 2006; Klingemann et al. 2010.

58 Hartleb 2007.

59 Novaković 2010.

60 Petsinis 2016.

61 It must be however also added that in general, parliamentary behavior of parties in questions of foreign policy is a recent object of study. See Parliamentary Deployment Votes Database for an example of a recent initiative: http://deploymentvotewatch.eu/.

62 Goldstein 2002.

63 Fitzgibbon and Guerra 2010.

64 Albertazzi and McDonnell 2005.

65 Jungar and Jupskås 2014.

66 Cincu 2017. 


\section{Countries, Topics and Parties Covered}

The majority of studies on populism and foreign policy focused on a specific country (45), and almost half focused on a specific party (31). Of the studies that focused on one country, the largest share was devoted to Italy (9), Germany (8) and France (6). When comparative studies are taken into account, Italy becomes the country discussed the most (20 studies), followed by France and Germany (15), Austria (13) and the Netherlands (12). Figure 2 below displays the full distribution of the countries that were studied is displayed below. A total of 54 studies discussed at least one political party in the opposition, and 36 did this for a coalition party. The parties that were discussed most were the Lega Nord (17), Front National and FPÖ (13), Danske Folkeparti (10), the Dutch LPF (8) and PVV (6) and the AFD (6). The Flemish Vlaams Blok and its successor Vlaams Belang combined were studied in 11 publications. Note that all of these parties can be classified as right-wing populist parties.$^{67}$ Figure 3 displays the full distribution of discussed parties in the selection.

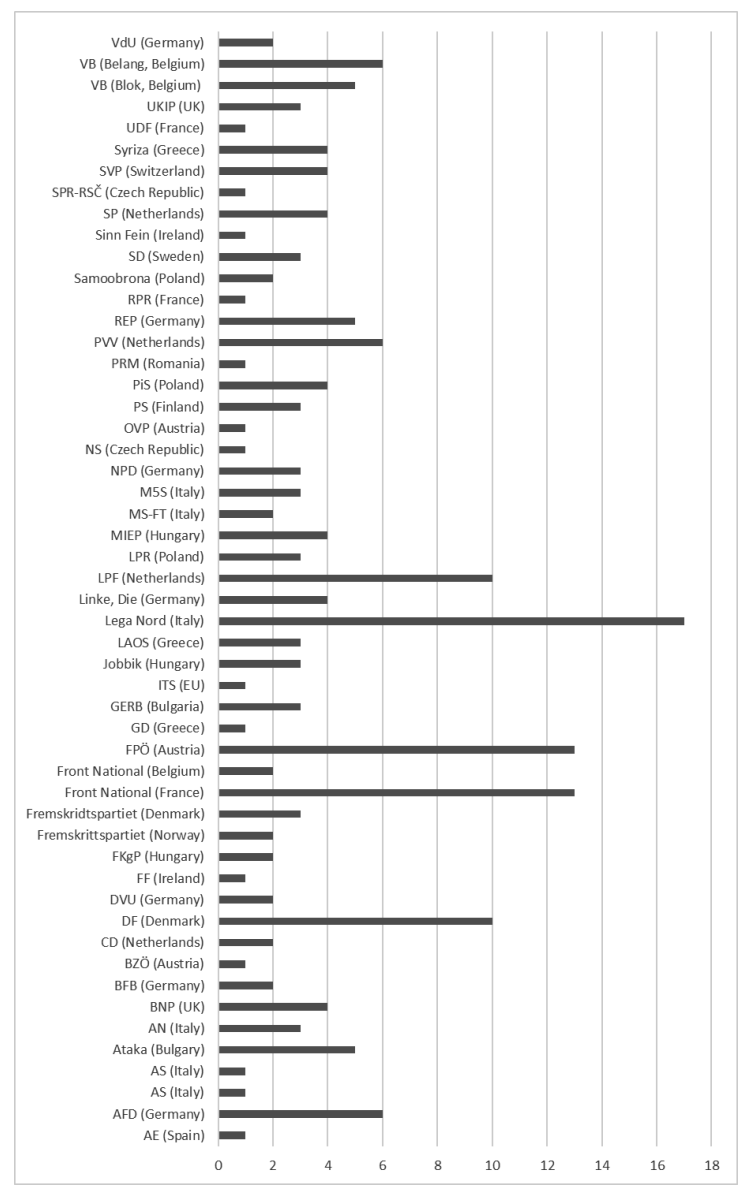

Figure 3: Which parties are covered?

67 Schori Liang 2007. 
When it comes to the themes, a vast majority of the studies discussed immigration politics (54) and EU politics (58). Significantly less attention was given to internationalism (globalization; 28 studies), mostly referred to as globalization. While most studies only touched upon the theme without any deeper analysis, the study by Woods ${ }^{68}$ is notable in focusing almost completely on the anti-globalization discourse of the Lega Nord. Foreign special relationships were discussed in 25 papers. The military was discussed in 20 papers, of which the study by Virchow ${ }^{69}$ is especially interesting: it provides an interesting and nuanced view on the FPÖ's discourse on the Austrian neutrality and military future. Twelve papers focused on state-centered anti-imperialism, most of the time this would be antiAmericanism. ${ }^{70}$ Thirteen papers looked at foreign financial influence, of which majority was dedicated to the international financial institutions. An example of this is the mistrust of the Hungarian MIÉP directed at the World Bank. ${ }^{71}$ In contrast, banks or other private financial companies would hardly be mentioned. Six papers looked at the theme of peace among the populist parties.

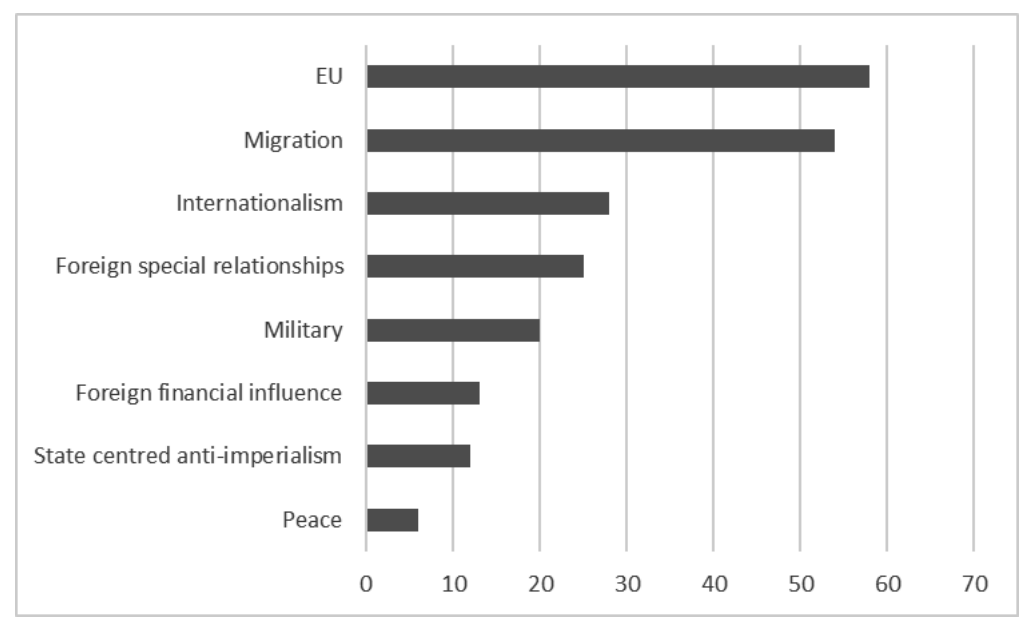

Figure 4: Which themes are covered?

Last but not least, we should note a significant conceptual confusion in the existing scholarship. The concepts of populism, extremism, and radicalism are very often mixed up. Often, these concepts are used interchangeably, without proper arguments on why a specific label can be applied to a political party. ${ }^{72}$ Scholars' choices for particular labels remain poorly argued, or under-substantiated. This could possibly hamper research advancing the scholarly expertise on certain political parties, for it is possible that some publications

68 Woods 2009.

69 Virchow 2016.

70 For an example, see Ghodsee 2008.

71 Weaver 2016.

72 For example, see Novaković 2010 or Cincu 2017. 
on populist parties were not found in our search based on definition differences. We did, however, treat the definition of populism lightly: only a brief mention of the populist character of a party would suffice to be included.

\section{Preferences of Populist Parties}

Beyond the definitional questions (of who populists are and what explains their success, two themes outside of the scope of our paper), there are two broad categories of research questions that guided the vast majority of the included publications. Firstly, what are the foreign policy preferences of populist parties, and how similar are these to those of other populist parties; and secondly, what happens when populist parties manage to occupy the seat of a coalition or governing party: do their preferences change, and how much influence do they have?

The answer to the first question, about the foreign policy preferences of populist parties, and how similar these are to those of other populist parties, is "it depends". Contributions in the volume edited by Christina Schori-Liang, ${ }^{73}$ found three major preferences: populist radical right parties are (1) against immigration, especially of Muslims (2) against globalization, often related to anti-Americanism, and (3) against the European Union. The comparative study by Chryssogelos indicates that these preferences are not necessarily held by left-wing populists. ${ }^{74} \mathrm{He}$ concludes that while all populists seem to share the anti-globalist discourse and often share the dislike for the EU, the left-leaning populist parties tend to reject the EU, not in itself but because of its current, 'neoliberal', form. Examples of this are Syriza and Podemos, who identify as Eurosceptic mainly because they oppose its austerity politics. ${ }^{75}$ Populist preferences concerning other policy fields, such as the military, tend to be less clear and more diffuse. For example, Ataka, SRP (Self-Defence), SP and the Lega Nord want to leave NATO, ${ }^{76}$ but AN, FPÖ, Vlaams Blok and PiS are pro-NATO. ${ }^{77}$

The second type of questions looked at what happens when populist parties manage to occupy the seat of a coalition or governing party, whether their preferences change, and how much influence they have. As theorized previously, political parties generally have two goals: gaining seats in the legislature and influencing the policies of their country. What becomes clear from our analysis, is that most primary sources that are used in the current body of literature indicate parties' preferences as they are communicated to the electorate and the larger public. In that sense, the publications often follow the parties'

73 Schori-Liang 2007.

74 Chryssogelos 2010.

75 Stavrakis 2014; Rodríguez-Teruel et al. 2016.

76 Fitzgibbon and Guerra 2010; Novakovic 2010; Lucardie and Voerman 2012.

77 Kopecký and Mudde 2002; Albertazzi and McDonnell 2005; Swyngedouw et al. 2007; Virchow 2007. It should be noted that such scholarship often provides a 'snapshot in time' view, and therefore it is possible that preferences of parties change over time. See, for example, Gustav Gressel 2017's comparison between FPÖ in 2000 and 2017. 
statements as they are intended to sway the electorate in their favor, and thus serve the first goal of the parties.

Recently, the research into what happens to the populist parties' foreign policy when they come into power gained more momentum. For example, in Verbeek \& Zaslove and Dobos \& Gyulai, the authors aim at reconstructing the influence that the selected populist party has on actual policy outcomes, and how they correspond to the intentions of the populist parties. $^{78}$

The few examples including parliamentary behavior sometimes noticed that there is a significant gap between discourse and practice. For example, the notable study by Cento Bull makes clear that while Lega Nord rhetoric on immigration did make its way in Italian legislation, the actual effects were limited due to other actors and the economic interests of its electorate. ${ }^{79}$ A similar study by Franzosi et al. noticed that the Five Star Movement is strategically Eurosceptic, but ideologically not, and thus differs significantly from other populist parties such as UKIP. ${ }^{80}$ This is a trend throughout the literature: Euroscepticism seems to be less extreme in practice, compared to populist rhetoric. ${ }^{81}$ As there is increasingly more data available on parliamentary behavior of parties in general, researchers should be encouraged to use this data also for the analysis of populist parties.

In contrast, the majority of publications lean heavily or fully on rhetoric analysis in media and manifestos and tend to treat populist parties as rather similar. Because of this, the variety of foreign policy ideologies and practices of populist parties tends to be overlooked in the literature. Based on what is known as of now, we would expect that more detailed studies of populist parliamentary behavior concerning foreign policy would indicate that these parties often share as much differences as similarities. However, at the moment we know very little about what laws and amendments populist parties propose, and how they behave in parliamentary committees.

\section{An Agenda for the Future}

Our study concluded that there is no such thing as a "populist foreign policy", and that we not only cannot conclude that populists are a threat to liberal international order, but also that we generally do not know much systematically about foreign policy preferences of populist parties. This is due to the four main shortcomings of the existing literature on foreign policy of populist parties which we identified. While we formulated our findings on the basis of the literature published up to the end of 2017, these shortcomings still

78 Verbeek and Zaslove 2015 and Dobos and Gyulai 2015.

79 Cento Bull 2010.

80 Franzosi et al. 2015.

81 For a more in-depth discussion of the strategy vs. ideology debate when it comes to EU-attitudes, see Kopecký and Mudde 2002. 
persist in the literature to a large degree today. We must note, however, that our findings do not stretch beyond the journals published in languages that we included in this review.

First, only a limited selection of methods is used by the scholars of populism and foreign policy. The vast majority of the studies used analysis of traditional media statements (36) and manifestos (48) to arrive at conclusions on the foreign policy preferences of populist parties. Given that the connection between social media and populism has been recently especially highlighted, ${ }^{82}$ it is rather surprising that there have been few studies thus far of the social media activities of populist parties. In light of the wide array of methods that are in use in political science to determine the ideology of political parties, ${ }^{83}$ the little variety in research methods concerning populism and foreign policy is striking. As tapping from more diverse sources of information could provide exciting, new insights on the foreign policy of populist parties, we invite scholars to apply innovative and triangulated methods.

Secondly, scholars should embrace a more systematic study of source documents. While some of the studies, such as Van Spanje \& Van der Brug ${ }^{84}$ and Reungoat ${ }^{85}$ systematically studied source documents, in the majority of studies scholars cite one or very few sweeping statements on one or two salient subjects. Triangulation has generally played a little role in the literature: many studies based their conclusions on use of limited number of sources. There are, however, positive examples: the study by Jungar \& Jupskås ${ }^{86}$ shows how the use of various methods can offer valuable insights; recent work by Özdamar \& Ceydilek ${ }^{87}$ demonstrates another example of systematic work using operational code analysis and the expert survey dataset gathered by Meijers \& Zaslove ${ }^{88}$ on the level of populism and basic foreign policy preferences of political parties in Europe is a promising example of systematic research. Still, the fact that few studies made use of systematic, indepth empirical investigation continues to pose a significant threat to our ability to study populist foreign policy.

Third, it becomes clear that the spotlight of academics studying populist parties focuses more heavily on some countries than others. Italy, with the Lega Nord, France, with the Front National, and Austria, with the FPÖ, are discussed by a high number of studies. This can partly be explained by the fact that these parties exist for a relatively long period, and partly because they have operated in the government as well as opposition ranks in their country. In that sense, it is interesting that, despite having operated on a national level for

82 Engesser et al. 2017.

83 Bakker et al. 2015; Laver and Garry 2000; Pennings et al. 2006.

84 Van Spanje and Van der Brug 2007.

85 Reungoat 2010.

86 Jungar and Jupskås 2014.

87 Özdamar and Ceydilek forthcoming.

88 Meijers and Zaslove forthcoming. 
only 4 years, the Dutch Pim Fortuyn List was a subject of 6 studies discussing the party, more than the Dutch PVV up to now.

Parties that have been studied have almost exclusively been defined as fully populist, whereas it has been argued that populism is a continuum that can be apparent in all parties to some extent. ${ }^{89}$ As a result, only the foreign policy of "hard populist" parties has been studied, ignoring potential relationships between foreign policy and moderate levels of populism.

The unequal division of attention among countries and parties becomes even more salient when considering how few studies exist on populist foreign policy preferences in Spain and Greece (at least in journals published in English, French, German or Dutch), where left-wing populism is prevalent. These European countries have seen parties that are often considered populist, such as Podemos and Syriza ${ }^{90}$ but have been severely understudied in the literature. Other "white spots on the European map" include Ireland, Portugal, Czech Republic, the Baltic States, and Romania. All of these countries share multi-party, democratic systems that by many definitions could have known some sort of populist parties since 1989, yet have been mostly neglected by researchers. While such countries have been covered in more recent studies of broader phenomena such as partisanship and foreign policy, ${ }^{91}$ there has been little scholarship that compared the conceptual study of populism with its empirical demonstration in Eastern Europe. Part of the reason for this oversight might have its roots in the inability of many scholars to read languages of Eastern European countries.

Fourth, and related, we observe a rather strange obsession with right-wing populist parties, and ignorance of left-wing populist parties. This might be related to the focus on countries where right-wing populist parties are prevalent and on topics that fit a rightwing populist discourse. Studies looking at Syriza, Podemos, Direction (Smer-SD), the Socialist Party in the Netherlands, or Estonian Center Party are almost completely missing (these parties were selected from the list provided in Table 1 of Santana and Rama ${ }^{92}$ ). This means that much of what we know about the populist foreign policy preferences are right-wing populist preferences. As there are significant differences between left-, right-wing and center parties in other areas of public policy, there is no reason to assume that this will not apply elsewhere (or we have no way of knowing before studying such phenomenon). There are indications that left-wing populist parties - such as Direction (SMER-SD) - behave differently compared to the right-wing populist parties when it comes to the parliamentary approval of missions abroad..$^{93}$ Overlooking left-wing

89 Rooduijn and Pauwels 2011.

90 Although there is a growing number of studies on Syriza, see Kioupkiolis 2016; Mudde 2016 ; Chryssogelos 2019.

91 Gressel 2017a; Wagner et al. 2018.

92 Santana and Rama 2018.

93 see Wagner et al. 2018. 
populism continues to be a significant problem for scholarship on populism and foreign policy. For example, a recent rather thorough operational code analysis of the foreign policy preferences of populist parties focused exclusively on the radical right. ${ }^{94}$ While we did not investigate the origins of this oversight, we suspect it might be related to the fact that right-wing populists have been in power in Western European countries which enjoy more spotlight in foreign policy literature anyway. A similar proposal, related to a more comparative study of populism, was issued by Mudde \& Rovira Kaltwasser. ${ }^{95}$ Taken together, these shortcomings create an opening for making the study of populism and foreign policy better and enrich the already flourishing research field.

Overall, there are good reasons to look at the link between populism and foreign policy. Studying populist foreign policy preferences helps to better understand populist parties. Foreign policy is often pictured as a matter of far-away places, in closed rooms, by educated and socialized elites. This appeals to the definitional opposition of populist parties towards corrupt elites. Combined with the apparent saliency to these parties of typical foreign policy themes such as migration and Euroscepticism, this exemplifies the tension between election rhetoric and actual policy making when entering a coalition. Moreover, as outlined previously in this paper, foreign policies cannot be understood without taking into account populist foreign policy preferences. The dynamics between political parties greatly shape foreign policy making of states, and many populist have at times played a dominant role in these dynamics.

Our research shows that the ways of studying and discussing populist foreign policy preferences influences what we know about them. The little variety in methods, for example, seems to relate to an overly homogeneous view of populist foreign policy preferences. The stereotypical populist party is right-wing, always against the European Union and migration and, when entering a coalition, adopts policies that are consistent with its electoral discourse. Reality is much more complex and nuanced than this.

Future research needs to expand the study of the links between populism and foreign policy to new methods and cases, in a more systematic fashion. Only then, we will be able to get more thorough understanding into how the populist zeitgeist is reflected in foreign policy in Europe.

94 Özdamar and Ceydilek forthcoming.

95 Mudde and Rovira Kaltwasser 2018. 


\section{References}

Albertazzi, Daniele, and Duncan McDonnell. 2005. "The Lega Nord in the second Berlusconi government: In a league of its own." West European Politics 28 (5): 952-972.

Aldrich, John H. 1995. Why parties? The origin and transformation of political parties in America. Chicago: University of Chicago Press.

Aslanidis, Paris. 2016. "Is populism an ideology? A refutation and a new perspective." Political Studies 64 (1_suppl): 88-104.

Bakker, Ryan, Catherine De Vries, Erica Edwards, Liesbet Hooghe, Seth Jolly, Gary Marks, Jonathan Polk, Jan Rovny, Marco Steenbergen, and Milada Vachudova. 2010. Chapel Hill Expert Survey. Chapel Hill, NC: University of North Carolina.

Batory, Agnes. 2016. "Populists in government? Hungary's 'system of national cooperation.' Democratization 23 (2): 283-303.

Betz, Hans-Georg. 1994. Radical right-wing populism in Western Europe. New York: St. Martin's.

Boucher, Jean-Christophe, and Cameron G. Thies. 2019. “I Am a Tariff Man': The Power of Populist Foreign Policy Rhetoric under President Trump." The Journal of Politics 81 (2): 712-722.

Browne, Eric C., and Mark N. Franklin.1973. "Aspects of coalition payoffs in European parliamentary democracies." American Political Science Review 67 (2):453-469.

Budge, Ian, and Richard I. Hofferbert. 1990. "Mandates and policy outputs: US party platforms and federal expenditures." American Political Science Review 84 (1): 111-131.

Budge, Ian, Hans-Dieter Klingemann, Andrea Volkens, Judith Bara, and Eric Tanenbaum. 2001. Mapping Policy Preferences: Estimates for Parties, Electors and Governments, 1945-1998. Oxford: Oxford University Press.

Cento Bull, Anna. 2010. "Addressing contradictory needs: the Lega Nord and Italian immigration policy" Patterns of Prejudice 44 (5): 411-431.

Chryssogelos, Angelos S. 2010. "Undermining the west from within: European populists, the US and Russia." European View 9 (2): 267-277.

Chryssogelos, Angelos. 2019. "Europeanisation as de-politicisation, crisis as repoliticisation: the case of Greek foreign policy during the Eurozone crisis." Journal of European Integration 41 (5): 605-621. 
Cincu, Adina Elena. 2017. "Far right populist challenge in Europe: Alternative for Germany and the National Front." Europolity 11 (1): 1-29.

Dobos, Gábor, and Attila Gyulai. 2015. "Promising Europe: EU Related Pledges and their Fulfilment in Hungarian Party Manifestos (1998-2010)." Politologický časopisCzech Journal of Political Science 22 (2): 87-104.

Dodson, Michael, and Manochehr Dorraj. 2008. "Populism and Foreign Policy in Venezuela and Iran Latin America." Whitehead Journal of Diplomacy and International Relations 9 (1): 71-88.

Drulák, Petr. 2009. "Introduction to the International Relations (IR) in Central and Eastern Europe Forum." Journal of International Relations and Development 12 (2): $168-173$.

Engesser, Sven, Nicole Ernst, Frank Esser, and Florin Büchel. 2017. "Populism and social media: How politicians spread a fragmented ideology" Information, Communication E Society 20 (8): 1109-1126.

Enyedi, Zsolt. 2016. "Paternalist populism and illiberal elitism in Central Europe." Journal of Political Ideologies 21 (1): 9-25.

Fearon, James D. 1998. "Domestic politics, foreign policy, and theories of international relations." Annual Review of Political Science 1 (1): 289-313.

Fitzgibbon, John, and Simona Guerra. 2010. "Not just Europeanization, not necessarily populism: Potential factors underlying the mobilization of populism in Ireland and Poland." Perspectives on European Politics and Society 11 (3): 273-291.

Franzosi, Paolo, Francesco Marone, and Eugenio Salvati. 2015. "Populism and Euroscepticism in the Italian Five Star Movement." The International Spectator 50 (2): 109-124.

Freeden, Michael. 1998. "Is nationalism a distinct ideology?” Political Studies 46 (4): $748-765$.

Friedrichs, Gordon. 2019. "A new grand bargain? Trumpian populism and shifts in the liberal economic order." In The Politics of Resilience and Transatlantic Order, edited by Gordon Friedrichs, Sebastian Harnisch, and Cameron G. Thies, 203-220. London: Routledge.

Ghodsee, Kristen. 2008. "Left wing, right wing, everything: xenophobia, neototalitarianism, and populist politics in Bulgaria." Problems of Post-Communism 55 (3): 26-39. 
Gidron, Noam, and Bart Bonikowski. 2013. "Varieties of populism: Literature review and research agenda." Working Paper. Cambridge: Weatherhead Center for International Affairs. Harvard University.

Goldstein, Kenneth. 2002. "Getting in the Door: Sampling and Completing Elite Interviews." PS: Political Science \& Politics 35 (4): 669-672.

Gressel, Gustav. 2017a. "Fellow travellers: Russia, anti-Westernism, and Europe's political parties." ECFR Policy Brief. Accessed July 10, 2017. http://www.ecfr.eu/page/-/ ECFR225_-_FELLOW_TRAVELLERS.pdf.

Gressel, Gustav. 2017b. “Austria: Russia's Trojan Horse?” ECFR. Accessed: February 6, 2017. https://www.ecfr.eu/article/commentary_austria_russias_trojan_horse.

Greven, Thomas. 2016. "The rise of right-wing populism in Europe and the United States. A Comparative Perspective [La emergencia del populismo de derechas en Europa y Estados Unidos. Una perspectiva comparada]". Washington DC Office: Friedrich Ebert Foundation.

Hartleb, Florian. 2007. "Party-based Euroscepticism in Germany." Romanian Journal of Political Science 7 (2): 13-30.

Heinisch, Reinhard. 2003. "Success in opposition-failure in government: explaining the performance of right-wing populist parties in public office." West European Politics 26 (3): $91-130$.

Hirsch Ballin, Ernst M. H. 2011. “Henk, Ingrid en de rechtsstaat.” In, Populisme: verrijking of bedreiging van de democratie? edited by J. Thomassen, 13-19. Amsterdam: Koninklijke Nederlandse Akademie van Wetenschappen.

Hiscox, Michael J. 2002. International trade and political conflict: commerce, coalitions, and mobility. Princeton: Princeton University Press.

Holliday, Shabnam J. 2016. “The legacy of subalternity and Gramsci's nationalpopular: populist discourse in the case of the Islamic Republic of Iran." Third World Quarterly 37 (5): 917-933.

Hooghe, Liesbet, Gary Marks, and Carole J. Wilson. 2002. "Does left/right structure party positions on European integration?” Comparative Political Studies 35 (8): 965-989.

Horowitz, Jason. 2018. “Italy's Populist Parties Agree on a Common Agenda to Govern." May 18. The New York Times. 
Hudson, Valerie M. 2005. "Foreign policy analysis: actor-specific theory and the ground of international relations.” Foreign Policy Analysis 1 (1): 1-30.

Jenne, Erin K., and Cas Mudde. 2012. “Can outsiders help?” Journal of Democracy 23 (3): 147-155.

Jerneck, Magnus, Anders Sannerstedt, and Mats Sjölin. 1988. "Internationalization and Parliamentary Decision-making: The Case of Sweden 1970-1985." Scandinavian Political Studies 11 (3): 169-194.

Joly, Jeroen, and Régis Dandoy. 2016. “Beyond the Water's Edge: How Political Parties Influence Foreign Policy Formulation in Belgium." Foreign Policy Analysis 14 (4): 512-535.

Jungar, Ann-Cathrine, and Anders Ravik Jupskås. 2014. "Populist radical right parties in the Nordic region: A new and distinct party family?" Scandinavian Political Studies 37 (3): 215-238.

Kioupkiolis, Alexandros. 2016. "Podemos: the ambiguous promises of left-wing populism in contemporary Spain." Journal of Political Ideologies 21 (2): 99-120.

Klingemann, Hans-Dieter, Andrea Volkens, Michael D. McDonald, Ian Budge, and Judith Bara. Mapping Policy Preferences II: Estimates for Parties, Electors and Governments in Eastern Europe, European Union and OECD, 1990-2003. Oxford: Oxford University Press.

Klingemann, Hans-Dieter, Richard I. Hofferbert, and Ian Budge. 1994. Parties, policies, and democracy. Oxford: Westview Press.

Koch, Michael T. 2009. "Governments, partisanship, and foreign policy: The case of dispute duration: Journal of Peace Research 46 (6): 799-817.

Koch, Michael T., and Patricia Sullivan. 2010. "Should I stay or should I go now? Partisanship, approval, and the duration of major power democratic military interventions." The Journal of Politics 72 (3): 616-629.

Koch, Michael T., and Skyler Cranmer. 2007. “Testing the 'Dick Cheney' hypothesis: do governments of the left attract more terrorism than governments of the right?" Conflict Management and Peace Science 24 (4): 311-326.

Kriesi, Hanspeter, Edgar Grande, Romain Lachat, Martin Dolezal, Simon Bornschier, and Timotheos Frey. 2006. "Globalization and the transformation of the national political space: Six European countries compared." European Journal of Political Research 45 (6): 921-956. 
Lavenex, Sandra. 2006. "Shifting up and out: The foreign policy of European immigration control." West European Politics 29 (2): 329-350.

Laver, Michael. 1998. "Party policy in Ireland 1997 results from an expert survey." Irish Political Studies 13 (1): 159-171.

Liberati, Alessandro, Douglas G. Altman, Jennifer Tetzlaff, Cynthia Mulrow, Peter C. Gøtzsche, John PA Ioannidis, Mike Clarke, Philip J. Devereaux, Jos Kleijnen, and David Moher. 2009. “The PRISMA statement for reporting systematic reviews and meta-analyses of studies that evaluate health care interventions: explanation and elaboration." Ann. Intern. Med 151: W65-W94.

Lipset, Seymour M., and Stein Rokkan. 1967. "Cleavage Structure, Party Systems and Voter Alignments: An Introduction." In Party Systems and Voter Alignments: Crossnational Perspectives, edited by Seymour M. Lipset and Stein Rokkan, 1-64. New York: Free Press.

Lucardie, Paul, and Gerrit Voerman. 2012. Populisten in de Polder. Amsterdam: Boom.

Lupia, Arthur, and Kaare Strøm. 1995. "Coalition termination and the strategic timing of parliamentary elections." American Political Science Review 89 (3): 648-665.

Marks, Gary, Carole J. Wilson, and Leonard Ray. 2002. "National political parties and European integration." American Journal of Political Science 46 (3): 585-594.

McDonnell, Duncan. 2006. "A weekend in Padania: regionalist populism and the Lega Nord”. Politics 26 (2): 126-132.

Meijers, Maurits J. and Zaslove, Andrej. forthcoming. "Measuring Populism in Political Parties: Appraisal of a New Approach." Comparative Political Studies. https://doi.org/10.1177/0010414020938081.

Mello, Patrick A. 2014. Democratic participation in armed conflict: military involvement in Kosovo, Afghanistan, and Iraq. Basingstoke: Palgrave.

Milner, Helen V., and Dustin Tingley. 2015. Sailing the water's edge: The domestic politics of American foreign policy. Princeton: Princeton University Press.

Milner, Helen V., and Benjamin Judkins. 2004. "Partisanship, trade policy, and globalization: Is there a left-right divide on trade policy?" International Studies Quarterly 48 (1): 95-119.

Mitchell, Christopher. 1989. "International migration, international relations and foreign policy.” International Migration Review 23 (3): 681-708. 
Moravcsik, Andrew. 1997. “Taking Preferences Seriously: A Liberal Theory of International Politics." International Organisation 51 (4): 513-553.

Mudde, Cas. 2004. “The populist zeitgeist." Government and Opposition 39 (4): 541-563.

Mudde, Cas. 2016. SYRIZA: The Failure of the Populist Promise. Cham: Springer.

Mudde, Cas, and Cristobal Rovira Kaltwasser. 2013. "Populism." In The Oxford Handbook of Political Ideologies, edited by Michael Freeden, Lyman Tower Sargent, and Marc Stears, 493. Oxford: Oxford University Press.

Mudde, Cas, and Cristobal Rovira Kaltwasser. 2018. "Studying Populism in Comparative Perspective: Reflections on the Contemporary and Future Research Agenda." Comparative Political Studies 51 (13): 1667-1693.

Novaković, Igor. 2010. "European" and "Extreme" Populists in the Same Row-the New Government of the Republic of Bulgaria." Western Balkans Security Observer 17: 63-76.

Ostermann, Falk, Bernhard Stahl, and Kai Oppermann. 2018. Radical Right Populism and Foreign Policy in France, Germany and the UK: Common Features and National Idiosyncrasies. Paper presented at the EISA European Workshops in International Relations (EWIS), 6-9 June 2018, Groningen, The Netherlands.

Özdamar, Özgür, and Erdem Ceydilek. forthcoming. "European populist radical right leaders' foreign policy beliefs: An operational code analysis." European Journal of International Relations. doi: 10.1177/1354066119850254.

Palmer, Glenn, Tamar London, and Patrick Regan. 2004. “What's stopping you?: The sources of political constraints on international conflict behavior in parliamentary democracies." International Interactions 30 (1): 1-24.

Pennings, Paul. 2017. "Trends in the partisan positions on internationalism and defence in Europe, 1945-2016." Paper presented at the Party Politics of Foreign and Security Policy in Europe, 5-6 October 2017, Amsterdam, The Netherlands.

Pennings, Paul, Hans Keman, and Jan Kleinnijenhuis. 2006. Doing research in political science: An introduction to comparative methods and statistics. Sage.

Pirro, Andrea LP, and Paul Taggart. 2018. "The populist politics of Euroscepticism in times of crisis: A framework for analysis." Politics 38 (3): 253-262.

Plagemann, Johannes, and Sandra Destradi. 2018. "Populism and Foreign Policy: The Case of India." Foreign Policy Analysis 15 (2): 283-301. 
Polk, Jonathan, Jan Rovny, Ryan Bakker, Erica Edwards, Liesbet Hooghe, Seth Jolly, Jelle Koedam, et al. 2017. "Explaining the salience of anti-elitism and reducing political corruption for political parties in Europe with the 2014 Chapel Hill Expert Survey data." Research E Politics 4 (1), https://doi.org/10.1177/2053168016686915.

Raunio, Tapio, and Wolfgang Wagner. 2017. “Towards parliamentarisation of foreign and security policy?" West European Politics 40 (1): 1-19.

Reungoat, Emmanuelle. 2010. "Anti-EU parties and the people: An analysis of populism in French Euromanifestos." Perspectives on European Politics and Society 11 (3): 292-312.

Rooduijn, Matthijs. 2014. "The mesmerising message: The diffusion of populism in public debates in Western European media." Political Studies 62 (4): 726-744.

Rovira Kaltwasser, Cristóbal, Paul A. Taggart, Paulina Ochoa Espejo, and Pierre Ostiguy, eds. 2017. The Oxford Handbook of Populism. Oxford: Oxford University Press.

Russett, Bruce. 1990. "Doves, hawks, and US public opinion." Political Science Quarterly 105 (4): 515-538.

Sagarzazu, Iñaki, and Cameron G. Thies. 2019. “The Foreign Policy Rhetoric of Populism: Chávez, Oil, and Anti-imperialism.” Political Research Quarterly 72 (1): 205-214.

Santana, Andrés, and José Rama. 2018. "Electoral support for left wing populist parties in Europe: addressing the globalization cleavage." European Politics and Society 19 (5): 558-576.

Schori-Liang, Christina, ed. 2007. Europe for the Europeans: The Foreign and Security Policy of the Populist Radical Right. Abingdon: Routledge.

Schori-Liang, Christina. 2007. “Nationalism Ensures Peace': the Foreign and Security Policy of the German Populist Radical Right After (Re) unification." In Europe for the Europeans: The Foreign and Security Policy of the Populist Radical Right, edited by Christina Schori-Liang, 157-194. London: Routledge.

Schumacher, Gijs, and Matthijs Rooduijn. 2013. "Sympathy for the 'devil'? Voting for populists in the 2006 and 2010 Dutch general elections." Electoral Studies 32 (1): $124-133$. 
Schuster, Jürgen, and Herbert Maier. 2006. “The rift: explaining Europe's divergent Iraq policies in the run-up of the American-led war on Iraq." Foreign Policy Analysis 2 (3): 223-244.

Slawson, Nicola. 2017. "Austrian president approves far-right Freedom party joining coalition government." The Guardian. Accessed September 10, 2020. https:// www.theguardian.com/world/2017/dec/16/austrian-president-approves-far-rightfreedom-party-role-in-coalition-government.

Stanley, Ben. 2008. “The thin ideology of populism.” Journal of Political Ideologies 13 (1): 95-110.

Strom, Kaare. 1990. "A behavioral theory of competitive political parties." American Journal of Political Science 34 (2): 565-598.

Swyngedouw, Marc, Koen Abts, and Maarten Van Craen. 2007. "Our own people first in a Europe of peoples. The international policy of the Vlaams Blok." In Europe for the Europeans: The foreign and security policy of the populist radical right, edited by Christina Schori-Liang, 81-101. London: Routledge.

Szirtes, George. 2018. "Here lies danger. Hungary is on the verge of full-blown autocracy" The Guardian. 30 March. Accessed September 10, 2020. https://www. theguardian.com/commentisfree/2018/mar/30/danger-hungary-verge-full-blownautocracy-viktor-orban-vengeance.

Taggart, Paul. 1998. "A touchstone of dissent: Euroscepticism in contemporary Western European party systems." European Journal of Political Research 33 (3): 363-388.

Taggart, Paul. 2000. Populism. Buckingham: Open University Press.

Taguieff, Pierre-André. 1995. "Political science confronts populism: from a conceptual mirage to a real problem." Telos (103): 9-43.

Thérien, Jean-Philippe, and Alain Noel. 2000. "Political parties and foreign aid." American Political Science Review 94 (1): 151-162.

Umland, Andreas. 2017. "Post-Soviet Neo-Eurasianism, the Putin System, and the Contemporary European Extreme Right." Perspectives on Politics 15 (2): 465-476.

Van der Brug, Wouter. 2001. "Perceptions, opinions and party preferences in the face of a real world event: Chernobyl as a natural experiment in political psychology" Journal of Theoretical Politics 13 (1): 53-80. 
Van Kessel, Stijn. 2011. Explaining the electoral performance of populist parties: The Netherlands as a case study. Perspectives on European Politics and Society 12 (1): 68-88.

Van Spanje, Joost, and Wouter van der Brug. 2007. "The party as pariah: The exclusion of anti-immigration parties and its effect on their ideological positions." West European Politics 30 (5): 1022-1040.

Verbeek, Bertjan, and Andrej Zaslove. 2015. “The impact of populist radical right parties on foreign policy: the Northern League as a junior coalition partner in the Berlusconi Governments." European Political Science Review 7 (4): 525-546.

Virchow, Fabian. 2016. "The Aims and Objections of the Austrian Far Right in the Fields of Foreign and Military Politics." In Europe for the Europeans: The foreign and security policy of the populist radical right, edited by Christina Schori-Liang, 73-98. London: Routledge.

Wagner, Wolfgang, Anna Herranz-Surrallés, Juliet Kaarbo, and Falk Ostermann. 2017. "The Party Politics of Legislative-Executive Relations in Security and Defence Policy." West European Politics 40 (1): 20-41.

Wagner, Wolfgang, Anna Herranz-Surrallés, Juliet Kaarbo, and Falk Ostermann. 2018. "Party politics at the water's edge: contestation of military operations in Europe." European Political Science Review 10 (4): 537-563.

Weaver, Eric Beckett. 2007. “The Communist Legacy? Populist but not Popular-The Foreign Policies of the Hungarian Radical Right." In Europe for the Europeans: The foreign and security policy of the populist radical right, edited by Christina SchoriLiang, 178-185. London: Routledge.

Werner, Annika, Onawa Lacewell, and Andrea Volkens. 2015. "Manifesto Coding Instructions: 5th fully revised edition."

Zuckerman, Alan S. 1982. "New approaches to political cleavage: A theoretical introduction." Comparative Political Studies 15 (2): 131-144. 


\section{Appendix 1: List of Articles Coded}

1. Adam, Robert. 2017. A populist momentum in the EU? Online Journal Modelling the New Europe 23: 19-30.

2. Akkerman, Tjitske. 2005. Anti-immigration parties and the defence of liberal values: The exceptional case of the List Pim Fortuyn. Journal of Political Ideologies 10 (3): 337-354.

3. Ahlemeyer, Volker. 2007. "A Specific Variant of Neo-Populism: Foreign and Security Policies of Extreme Right Parties in the European Parliament Elections in 2004." In Europe for the Europeans: The foreign and security policy of the populist radical right, edited by Christina Schori-Liang, 283-295. London: Routledge.

4. Albertazzi, Daniele, and Duncan McDonnell. 2005. "The Lega Nord in the second Berlusconi government: In a league of its own." West European Politics 28 (5): 952-972.

5. Andersen, Jørgen G. 2007. "Nationalism, new right, and new cleavages in Danish politics: Foreign and security policy of the Danish People's Party." In Europe for the Europeans: The foreign and security policy of the populist radical right, edited by Christina Schori-Liang, 103-123. London: Routledge.

6. Bordignon, Fabio, and Luigi Ceccarini. 2013. "Five stars and a cricket. Beppe Grillo shakes Italian politics." South European Society and Politics 18 (4): 427-449.

7. Cento Bull, Anna. 2010. "Addressing contradictory needs: the Lega Nord and Italian immigration policy." Patterns of Prejudice 44 (5): 411-431.

8. Chiantera-Stutte, Patricia. 2002. Das Europa der Antieuropäer Ein Vergleich von Lega Nord und FPÖ. EUI Working Paper SPS No. 2002/9.

9. Chiantera-Stutte, Patricia, and Andrea Petö. 2003. "Cultures of populism and the political right in Central Europe." CLCWeb: Comparative Literature and Culture 5 (4): 2.

10. Chryssogelos, Angelos-Stylianos. 2010. "Undermining the west from within: European populists, the US and Russia." European View 9 (2): 267-277.

11. Cincu, Adina E. 2017. "Far right populist challenge in Europe: Alternative for Germany and the National Front." Europolity 11 (1): 21-49. 
12. Cocuz, Iona. 2017. "Reframing the European Union in French nationalist discourse by Marine Le Pen." Synergy 13 (1).

13. Decker, Frank. 2015. "Alternative für Deutschland und Pegida: Die Ankunft des neuen Rechtspopulismus in der Bundesrepublik." In Rechtspopulismus und Rechtsextremismus in Europa edited by Frank Decker, Bernd Henningsen and Kjetil A. Jakobsen, 75-90. Nomos Verlagsgesellschaft mbH \& Co. KG.

14. Decker, Frank, and Florian Hartleb. 2007. "Populism on difficult terrain: The right-and left-wing challenger parties in the Federal Republic of Germany." German Politics 16 (4): 434-454.

15. Dobos, Gábor, and Attila Gyulai. 2015. "Promising Europe: EU Related Pledges and their Fulfilment in Hungarian Party Manifestos (1998-2010)." Politologický časopis-Czech Journal of Political Science 22 (2): 87-104.

16. Evans, Jocelyn A.J. 2007. “La politique du dehors avec les raisons du dedans': Foreign and Defence Policy of the French Front National." In Europe for the Europeans: The foreign and security policy of the populist radical right, edited by Christina Schori-Liang, 143-156. London: Routledge.

17. Fitzgibbon, Joh, and Simona Guerra. 2010. "Not just Europeanization, not necessarily populism: Potential factors underlying the mobilization of populism in Ireland and Poland." Perspectives on European Politics and Society 11 (3): 273-291.

18. Franzosi, Paolo, Francesco Marone, and Eugenio Salvati. 2015. "Populism and Euroscepticism in the Italian Five Star Movement." The International Spectator 50 (2): 109-124.

19. Ghodsee, Kristen. 2008. "Left wing, right wing, everything: xenophobia, neototalitarianism, and populist politics in Bulgaria." Problems of Post-Communism 55 (3): 26-39.

20. Giuliani, Jean-Dominique. 2016. "Extrémismes, populismes et nationalismes à l'assaut de l'Europe." Politique étrangère (2): 103-111.

21. Griffin, Roger. 2007. "Non Angeli, sed Angli: The neo-populist foreign policy of the 'New' BNP." In Europe for the Europeans: The foreign and security policy of the populist radical right, edited by Christina Schori-Liang, 239-259. London: Routledge.

22. Guérot, Ulrike. 2015. "Marine Le Pen und die Metamorphose der französischen Republik." Leviathan 43 (2): 177-212. 
23. Hartleb, Florian. 2007. "Party-based Euroscepticism in Germany." Romanian Journal of Political Science 7 (2): 13-30.

24. Jakobsen, Kjetil A. 2015. "Aufstand der Bildungsverlierer? Die Fortschrittspartei auf dem norwegischen Sonderweg." In Rechtspopulismus und Rechtsextremismus in Europa edited by Frank Decker, Bernd Henningsen and Kjetil A. Jakobsen, 147-164. Nomos Verlagsgesellschaft mbH \& Co. KG.

25. Jungar, Ann-Cathrine, and Anders Ravik Jupskås. 2014. "Populist Parties in the Nordic Region: Towards A New Party Family?” Scandinavian Political Studies 37 (3): 215-238.

26. Jungar, Ann-Cathrine. 2015. "Convergence by different means: the Finns Party and the Sweden Democrats." In Rechtspopulismus und Rechtsextremismus in Europa edited by Frank Decker, Bernd Henningsen and Kjetil A. Jakobsen, 187204. Nomos Verlagsgesellschaft mbH \& Co. KG.

27. Katsambekis, Giorgos. 2016. "Radical left populism in contemporary Greece: Syriza's trajectory from minoritarian opposition to power." Constellations 23 (3): 391-403.

28. Kessel, van Stijn. 2015. "Right-wing populism in contemporary Dutch politics." In Rechtspopulismus und Rechtsextremismus in Europa, edited by Frank Decker, Bernd Henningsen and Kjetil A. Jakobsen, 205-216. Nomos Verlagsgesellschaft $\mathrm{mbH} \&$ Co. KG.

29. Kioupkiolis, Alexandros. 2016. "Podemos: the ambiguous promises of left-wing populism in contemporary Spain." Journal of Political Ideologies 21 (2): 99-120.

30. Kopecký, Petr, and Cas Mudde. 2002. “The two sides of Euroscepticism: party positions on European integration in East Central Europe." European Union Politics 3 (3): 297-326.

31. Kopke, Christoph, and Alexander Lorenz. 2017. "Zwischen konservativem Nationalpopulismus und fundamentaloppositioneller Bewegung Das aktuelle Profil der AfD in Brandenburg." In AfD \& FPÖ Antisemitismus, völkischer Nationalismus und Geschlechterbilder, edited by Stephan Grigat, 79-100. Nomos Verlagsgesellschaft mbH \& Co. KG.

32. Lloyd, John. 2003. "The closing of the European gates? The new populist parties of Europe." The Political Quarterly 74 (s1): 88-99.

33. Lucardie, Paul, and Gerrit Voerman. 2012. Populisten in de Polder. Meppel: Boom. 
34. Mazzoleni, Oscar. 2007. “The Swiss People's Party and the Foreign and Security Policy since the 1990s." In Europe for the Europeans: The foreign and security policy of the populist radical right, edited by Christina Schori-Liang, 223-239. London: Routledge.

35. Mazzoleni, Oscar. 2015. "Between opposition and government: The Swiss People's party." In Rechtspopulismus und Rechtsextremismus in Europa, edited by Frank Decker, Bernd Henningsen and Kjetil A. Jakobsen, 111-128. Nomos Verlagsgesellschaft mbH \& Co. KG.

36. McDonnell, Duncan. 2006. "A weekend in Padania: regionalist populism and the Lega Nord." Politics 26 (2): 126-132.

37. Mudde, Cas. 2007. "A Fortuynist foreign policy." In Europe for the Europeans: The foreign and security policy of the populist radical right, edited by Christina Schori-Liang, 209-222. London: Routledge.

38. Novaković, Igor. 2010. “European' and 'Extreme' Populists in the Same Rowthe New Government of the Republic of Bulgaria." Western Balkans Security Observer-English Edition 17: 63-76.

39. Petsinis, Vassilis. 2016. "Russophilia as a component of national populism in Greece." Critique \& Humanism 46 (2): 281-298.

40. Reungoat, Emmanuelle. 2010. "Anti-EU parties and the people: An analysis of populism in French Euromanifestos." Perspectives on European Politics and Society 11 (3): 292-312.

41. Rodríguez-Teruel, Juan, Astrid Barrio, and Oscar Barberà. 2016. "Fast and furious: Podemos' quest for power in multi-level Spain.” South European Society and Politics 21 (4): 561-585.

42. Rosenfelder, Joel. 2017. "Die Programmatik der AfD: Inwiefern hat sie sich von einer primär euroskeptischen zu einer rechtspopulistischen Partei entwickelt?” ZParl Zeitschrift für Parlamentsfragen 48 (1): 123-140.

43. Schori-Liang, Christina. 2007. "Europe for the Europeans: Introduction." In Europe for the Europeans: The foreign and security policy of the populist radical right, edited by Christina Schori-Liang, 1-32. London: Routledge.

44. Schori-Liang, Christina. 2007. 'Nationalism Ensures Peace': the Foreign and Security Policy of the German Populist Radical Right After (Re) unification." In Europe for the Europeans: The foreign and security policy of the populist radical right, edited by Christina Schori-Liang, 139-175. London: Routledge. 
45. Stavrakakis, Yannis, and Giorgos Katsambekis. 2014. "Left-wing populism in the European periphery: the case of SYRIZA." Journal of Political Ideologies 19 (2): 119-142.

46. Styczyńska, Natasza. 2015. “(Non) Existence of Bulgarian Party-Based Euroscepticism-Why Should We Care?” Politeja. Pismo Wydziału Studiów Miedzynarodowych i Politycznych Uniwersytetu Jagiellońskiego 2: 201-214.

47. Sutcliffe, John B. 2012. "The roots and consequences of Euroskepticism: an evaluation of the United Kingdom Independence Party." Geopolitics, History and International Relations 4 (1): 107-127.

48. Swyngedouw, Marc, Koen Abts, and Maarten Van Craen. 2007. "Our own people first in a Europe of peoples. The international policy of the Vlaams Blok." In Europe for the Europeans: The foreign and security policy of the populist radical right, edited by Christina Schori-Liang, 81-101. London: Routledge.

49. Taggart, Paul. 1998. "A touchstone of dissent: Euroscepticism in contemporary Western European party systems.” European Journal of Political Research 33 (3): $363-388$.

50. Tarchi, Marco. 2007. "Recalcitrant Allies: The Conflicting Foreign Policy Agenda of the Alleanza Nazionale and the Lega Nord." In Europe for the Europeans: The foreign and security policy of the populist radical right, edited by Christina Schori-Liang, 205-226. London: Routledge.

51. Van Spanje, Joost, and Wouter Van Der Brug. 2007. “The party as pariah: The exclusion of anti-immigration parties and its effect on their ideological positions." West European Politics, 30 (5): 1022-1040.

52. Vasilopoulou, Sofia. 2011. "European integration and the radical right: Three patterns of opposition." Government and Opposition 46 (2): 223-244.

53. Verbeek, Bertjan, and Andrej Zaslove. 2015. "The impact of populist radical right parties on foreign policy: the Northern League as a junior coalition partner in the Berlusconi Governments." European Political Science Review 7 (4): 525-546.

54. Verbeek, Bertjan, and Andrej Zaslove. 2017. "Populism and Foreign Policy." In Oxford Handbook of Populism, edited by Christóbal Rovira Kaltwasser, Paul Taggart, Paulina Ochoa Espejo, Pierre Ostiguy, 384-405. Oxford: Oxford University Press. 
55. Virchow, Fabian. 2007. "The Aims and Objections of the Austrian Far Right in the Fields of Foreign and Military Politics." In Europe for the Europeans: The foreign and security policy of the populist radical right, edited by Christina Schori-Liang, 73-98. London: Routledge.

56. Vossen, Koen. 2011. "Classifying wilders: the Ideological development of Geert Wilders and his party for freedom." Politics 31 (3): 179-189.

57. Weaver, Eric Beckett 2007. “The Communist Legacy? Populist but not Popular-The Foreign Policies of the Hungarian Radical Right." In Europe for the Europeans: The foreign and security policy of the populist radical right, edited by Christina Schori-Liang, 178-185. London: Routledge.

58. Wilkoń, Łukasz 2016. "The Populist Chameleon: some general considerations on Lega Nord ideology" Studia Politicae Universitatis Silesiensis (17): 158-182.

59. Wirries, Clemens. 2015. "Populismus und Pragmatismus. Genese und Etablierung der Dänischen Volkspartei." In Rechtspopulismus und Rechtsextremismus in Europa edited by Frank Decker, Bernd Henningsen and Kjetil A. Jakobsen, 129-146. Nomos Verlagsgesellschaft mbH \& Co. KG.

60. Wolf, Tanja. 2016. Is the Alternative for Germany Really Right-Wing Populist? Politologický časopis-Czech Journal of Political Science 23 (2): 149-163.

61. Woods, Dwayne. 2009. "Pockets of resistance to globalization: the case of the Lega Nord." Patterns of Prejudice 43 (2): 161-177.

62. Zaslove, Andrej. 2004. "Closing the door? The ideology and impact of radical right populism on immigration policy in Austria and Italy." Journal of Political Ideologies 9 (1): 99-118. 


\section{Appendix 2: Coding Scheme}

\begin{tabular}{|c|c|}
\hline Category & Definition \\
\hline \multicolumn{2}{|l|}{ Research method } \\
\hline Theoretical analysis & $\begin{array}{l}\text { The study devotes a significant portion of text to analyzing existing } \\
\text { theories on populism and foreign policy and/or proposes a new } \\
\text { theoretical framework. }\end{array}$ \\
\hline Literature review & $\begin{array}{l}\text { A review of the literature on this party served as a source for the } \\
\text { article. }\end{array}$ \\
\hline Interviews & $\begin{array}{l}\text { Interviews with (leading) members of the populist party served as a } \\
\text { source for the article. These interviews are to be held by the author } \\
\text { personally, otherwise it is categorized as "traditional media analysis". }\end{array}$ \\
\hline Traditional media analysis & $\begin{array}{l}\text { Any statement by the party, primarily published via traditional } \\
\text { media, served as a source for the article. }\end{array}$ \\
\hline Social media analysis & $\begin{array}{l}\text { Any statement by the party, primarily published on a social medium, } \\
\text { served as a source for the article. }\end{array}$ \\
\hline Expert survey & The opinion of experts served as a source for the article. \\
\hline parliamentary behavior analysis & $\begin{array}{l}\text { An analysis of voting behavior in parliament served as a source for } \\
\text { the article. This also included speeches or statements in parliament } \\
\text { law texts. }\end{array}$ \\
\hline Manifesto analysis & $\begin{array}{l}\text { The party manifesto served as a source for the article. Online } \\
\text { publications were included in this category as well, if it was not } \\
\text { primarily published using a newspaper's website or social medium. } \\
\text { Books written by a representative of the political party were } \\
\text { included in this category too. }\end{array}$ \\
\hline \multicolumn{2}{|l|}{ Research scope } \\
\hline Party-specific & The article focuses on a specific party. \\
\hline Country-specific & The article focuses on a specific country. \\
\hline \multicolumn{2}{|l|}{ Party characteristics } \\
\hline Country & $\begin{array}{l}\text { This indicates the country in which one or more of the populist } \\
\text { parties that are discussed in the article operates. All democratic } \\
\text { countries on the European continent are included. }\end{array}$ \\
\hline coalition party & $\begin{array}{l}\text { One or more populist party as discussed in the article has been a } \\
\text { coalition party within the timeframe that the article discusses its } \\
\text { ideology }\end{array}$ \\
\hline opposition party & $\begin{array}{l}\text { One or more populist party as discussed in the article has been an } \\
\text { opposition party within the timeframe that the article discusses its } \\
\text { ideology }\end{array}$ \\
\hline \multicolumn{2}{|l|}{ International relations subjects } \\
\hline Foreign special relationships & $\begin{array}{l}\text { Mentions of particular countries with which the manifesto country } \\
\text { has a special relationship; the need for co-operation with and/or aid } \\
\text { to such countries. }\end{array}$ \\
\hline
\end{tabular}




\begin{tabular}{|c|c|}
\hline State-centered anti-imperialism & $\begin{array}{l}\text { Negative references to imperial behavior and/or negative references } \\
\text { to one state exerting strong influence (political, military or } \\
\text { commercial) over other states. May also include: } \\
\text { - Negative references to controlling other countries as if they were } \\
\text { part of an empire; } \\
\text { - Favorable references to greater self-government and } \\
\text { independence for colonies; } \\
\text { - Favorable mentions of de-colonization. }\end{array}$ \\
\hline Foreign financial influence & $\begin{array}{l}\text { References and statements on international financial organizations } \\
\text { or states using monetary means and their influence over the country. } \\
\text { May include: } \\
\text { - Statements on the World Bank, IMF etc.; } \\
\text { - Statements about foreign debt circumscribing state actions. }\end{array}$ \\
\hline Military & $\begin{array}{l}\text { References to the military or use of military power to solve conflicts, } \\
\text { including: } \\
\text { - } \quad \text { Military expenditure; } \\
\text { - Manpower in the military; } \\
\text { - } \quad \text { Modernization of the armed forces and improvement of the } \\
\text { military strength; } \\
\text { - } \quad \text { Rearmament and self-defense; } \\
\text { - Military treaty obligations. }\end{array}$ \\
\hline Peace & Any reference to peace \\
\hline Internationalism & $\begin{array}{l}\text { International cooperation, including cooperation with specific } \\
\text { countries other than those coded in "foreign special relationships". } \\
\text { May also include references to: } \\
\text { - Aid to developing countries; } \\
\text { - World planning of resources; } \\
\text { - Global governance; } \\
\text { - International courts; } \\
\text { - The UN or other international organizations; } \\
\text { - National independence and sovereignty with regard to the } \\
\text { manifesto country's foreign policy }\end{array}$ \\
\hline European Union & $\begin{array}{l}\text { Mentions of European Community/Union in general. May include: } \\
\text { - Desirability of the manifesto country joining (or remaining a } \\
\text { member); } \\
\text { - Desirability of expanding the European Community/Union; } \\
\text { - Desirability of increasing the ECs/EU's competences; } \\
\text { - Desirability of expanding the competences of the European } \\
\text { Parliament. }\end{array}$ \\
\hline Migration & $\begin{array}{l}\text { References to migration, including: } \\
\text { - The number of migrants the country should accept; } \\
\text { - How the country should handle migrants; } \\
\text { - } \quad \text { References to international agreements on migration policies. }\end{array}$ \\
\hline
\end{tabular}

